JORGE SANCHEZ, MD

Department of Internal Medicine, MacNeal Internal

Medicine Resident Program, Berwyn, IL
ROBERT LICHTENBERG, MD

Department of Internal Medicine, MacNeal Hospital, Berwyn, IL

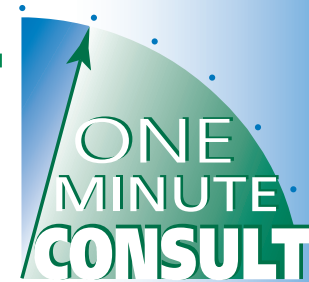

BRIEF ANSWERS

TO SPECIFIC

CLINICAL

QUESTIONS

\title{
: Does my patient need maintenance fluids?
}

ume depletion, drugs, pathologic medical conditions, or syndrome of inappropriate ADH stimulation?

- Will my patient be receiving strictly nothing by mouth?

- Are there unusual fluid losses?

\section{SCENARIO 1: 'USUAL' MAINTENANCE}

If the patient is euvolemic, with a normal serum osmolality, a GFR more than $60 \mathrm{~mL} /$ $\min / 1.73 \mathrm{~m}^{2}$, no stimuli for ADH secretion, and no unusual fluid losses, "usual" maintenance would be expected. The usual volume for this patient can be estimated by the following formulas:

- Maintenance volume: $2,550 \mathrm{~mL}(1,500$ $\mathrm{mL} \times 1.7 \mathrm{~m}^{2}$ body surface area)

- Holliday-Segar method ${ }^{6}: 2,500$ mL (1,500 $\mathrm{mL}$ plus $20 \mathrm{~mL} / \mathrm{kg}$ for every kilogram over $20 \mathrm{~kg}$ ).

The usual sodium can be also estimated by the following formulas:

- $2 \mathrm{~g} \mathrm{Na} /$ day $=2,000 \mathrm{mg} /$ day $=87 \mathrm{mEq} /$ day

- Holliday-Segar ${ }^{6}: 3 \mathrm{mEq} \mathrm{Na} / 100 \mathrm{~mL}$ and 2 $\mathrm{mEq} \mathrm{K/100} \mathrm{mL} \mathrm{of} \mathrm{maintenance} \mathrm{fluid.}$

Maintenance IV fluids for our nonacutely ill adult patient could be:

- NICE guideline ${ }^{5}$ : D5W in $0.2 \% \mathrm{NaCl}_{\text {with }}$ $20 \mathrm{mEq} \mathrm{KCl}$, to run at $75 \mathrm{~mL} / \mathrm{hour}$

- Holliday-Segar method ${ }^{6}$ : D5W in $0.2 \%$ $\mathrm{NaCl}$ with $20 \mathrm{mEq} \mathrm{KCl}$, to run at $100 \mathrm{~mL} /$ hour.

Twenty-four hours later, assuming no unusual fluid losses or stimulation of $\mathrm{ADH}$ secretion, our patient would weigh the same and would have no significant change in serum osmolality.

\section{OTHER OPTIONS}

\section{What if I provide $0.9 \% \mathrm{NaCl}$ instead?}

Each $1 \mathrm{~L}$ of normal saline provides $154 \mathrm{mEq}$ of sodium, equivalent to $3.5 \mathrm{~g}$ of sodium.
The question

seems like it should have an

easy answer.

However, there

is no consensus

on either the

type of fluid or the need for

them at all. 


\section{TABLE 1}

Scenario 1: 24 hours without fluids

\begin{tabular}{|c|c|c|c|c|c|c|c|c|c|}
\hline & \multicolumn{3}{|c|}{ Total body } & \multicolumn{3}{|c|}{ Intracellular } & \multicolumn{3}{|c|}{ Extracellular } \\
\hline & Volume & Osm/L & $\begin{array}{l}\text { Total } \\
\text { osmoles }\end{array}$ & Volume & Osm/L & $\begin{array}{l}\text { Total } \\
\text { osmoles }\end{array}$ & Volume & Osm/L & $\begin{array}{l}\text { Total } \\
\text { osmoles }\end{array}$ \\
\hline Baseline & $42.0 \mathrm{~L}$ & 280.0 & 11,760 & $28.0 \mathrm{~L}$ & 280.0 & 7,840 & $14.0 \mathrm{~L}$ & 280.0 & 3,920 \\
\hline Losses & $-2.5 \mathrm{~L}$ & & -166 & & & & & & -166 \\
\hline New state & $39.5 \mathrm{~L}$ & 293.5 & 11,594 & $26.7 \mathrm{~L}$ & 293.5 & 7,840 & $12.8 \mathrm{~L}$ & 293.5 & 3,764 \\
\hline
\end{tabular}

Thus, for the 24 hours, with administration of 2 to $2.5 \mathrm{~L}$, the patient would receive a sodium load of 7 to $8.75 \mathrm{~g}$. The consequences of this can be debated, but for 24 hours, more than likely, nothing will happen or be noticeable. The kidneys have a wonderful ability to "dump" excess sodium ingested in the diet, as evidenced by the average Western diet with a sodium load in the range of $4 \mathrm{~g}$ per day. ${ }^{7,8}$

\section{What if I provide $0.45 \% \mathrm{NaCl}$ instead?}

Each liter provides $50 \%$ of the sodium load of $0.9 \% \mathrm{NaCl}$. With the 24-hour administration of 2 to $2.5 \mathrm{~L}$ of D $5 \mathrm{~W}$ in $0.45 \% \mathrm{NaCl}$, the sodi-

Heart failure and renal disease put the patient at risk of either hyponatremia or sodium overload um load would be 3.5 to $4.8 \mathrm{~g}$, and the kidneys would dump the excess sodium.

\section{What if I provide 'catch-up' fluids after $\mathbf{2 4}$ hours, not maintenance fluids?}

Assuming only usual losses and no unusual ADH stimulation except for the physiologic stimuli from volume depletion for 24 hours, our patient would lose $2 \mathrm{~kg}$ ( $1 \mathrm{~L}$ fluid loss $=1$ $\mathrm{kg}$ weight loss) and $87 \mathrm{mEq}$ of sodium. This is approximately $4.5 \%$ dehydration; thus, other than increased thirst, no physical findings of volume depletion would be clinically evident.

However, serum osmolality and sodium would increase. After 24 hours of nothing by mouth with usual fluid losses, there would be a rise in serum osmolality of $13.5 \mathrm{mOsm} / \mathrm{L}$ (a rise in sodium of 6 to $7 \mathrm{mEq} / \mathrm{L}$ ), which would stimulate $\mathrm{ADH}$ in an attempt to minimize further urinary losses. There would be an intracellular volume loss of $1.3 \mathrm{~L}$ (Table 1). Clinically, just as with the administration of $0.9 \%$ sodium, these changes would not likely be of any clinical consequence in the first 24 hours.

\section{SCENARIO 2: IMPAIRED WATER EXCRETION, AND FLUIDS GIVEN}

If the patient is euvolemic but has or is at risk for $\mathrm{ADH}$ stimulation, ${ }^{1,9}$ providing maintenance IV fluids according to the NICE or Holliday-Segar recommendations (a total of $2 \mathrm{~L}$ of $0.2 \% \mathrm{NaCl}=34 \mathrm{mEq} \mathrm{Na} / \mathrm{L}=68 \mathrm{mOsm} / \mathrm{L}$ ) would result in an excess of free water, as an increase in $\mathrm{ADH}$ secretion impairs free water clearance. A potential scenario with impaired water excretion is shown in Table 2.

After 24 hours, the patient's serum osmolality would drop by about $7 \mathrm{mOsm} / \mathrm{L}$, and the serum sodium would decrease by 3 or $4 \mathrm{mEq}$. The consequence of the intracellular fluid shift would be seen by the expansion of the intracellular volume from 28 to $28.7 \mathrm{~L}$.

If this patient were to have received $2 \mathrm{~L}$ of $0.9 \% \mathrm{NaCl}(308 \mathrm{mOsm} / \mathrm{L} \times 2 \mathrm{~L}=616 \mathrm{Osm})$ as suggested by Moritz and Ayus, ${ }^{1}$ the result would be a serum osmolality of $284 \mathrm{mOsm} / \mathrm{L}$, thus avoiding hyponatremia and intracellular fluid shifts.

\section{THE BOTTOM LINE}

Know your patient, answer the clinical questions noted above, and decide.

For a euvolemic patient with normal serum sodium, GFR greater than $60 \mathrm{~mL} / 1.73 \mathrm{~m}^{2}$, and no $\mathrm{ADH}$ stimulation, for 24 hours it probably doesn't matter that much, but a daily reassessment of the continued need for and type of intravenous fluids is critical.

For patients not meeting the criteria noted above such as a patient with systolic or diastolic heart failure, advanced or end-stage renal disease puts the patient at risk for early potential complications of either hyponatremia or sodi- 


\section{TABLE 2}

\section{Scenario 2: Antidiuretic hormone stimulation and 2L of $0.2 \% \mathrm{NaCl}$ in 24 hours}

\begin{tabular}{|c|c|c|c|c|c|c|c|c|c|}
\hline & \multicolumn{3}{|c|}{ Total body } & \multicolumn{3}{|c|}{ Intracellular } & \multicolumn{3}{|c|}{ Extracellular } \\
\hline & Volume & Osm/L & $\begin{array}{l}\text { Total } \\
\text { osmoles }\end{array}$ & Volume & Osm/L & $\begin{array}{l}\text { Total } \\
\text { osmoles }\end{array}$ & Volume & Osm/L & $\begin{array}{l}\text { Total } \\
\text { osmoles }\end{array}$ \\
\hline Baseline & $42.0 \mathrm{~L}$ & 280 & 11,760 & $28.0 \mathrm{~L}$ & 280.0 & 7,840 & $14.0 \mathrm{~L}$ & 280.0 & 3,920 \\
\hline Losses & $-1.0 \mathrm{~L}$ & & -166 & & & & & & -166 \\
\hline Fluids given & $+2.0 \mathrm{~L}$ & & +136 & & & & & & +136 \\
\hline New state & $43.0 \mathrm{~L}$ & 272.7 & 11,730 & $28.7 \mathrm{~L}$ & 272.7 & 7,840 & $14.3 \mathrm{~L}$ & 272.7 & 3,890 \\
\hline
\end{tabular}

um overload. For these patients, maintenance intravenous fluids need to be chosen wisely. Daily weights, examinations, and laboratory

\section{REFERENCES}

1. Mortiz ML, Ayus JC. Maintenance intravenous fluids in acutely ill patients. N Engl J Med 2015; 373(14):1350-1360. doi:10.1056/NEJMra1412877

2. Feld LG, Neuspiel DR, Foster BA, et al; Subcommittee on Fluid and Electrolyte Therapy. Clinical practice guideline: maintenance intravenous fluids in children. Pediatrics 2018;142(6). doi:10.1542/peds.2018-3083

3. Sterns RH. Maintenance and replacement fluid therapy in adults. www.uptodate.com/contents/maintenance-and-replacement-fluidtherapy-in-adults. Accessed August 21, 2019.

4. Shafiee MA, Bohn D, Hoorn EJ, Halperin ML. How to select optimal maintenance intravenous fluid therapy. QJM 2003; 96(8):601-610. doi:10.1093/qjmed/hcg101

5. National Institute for Health and Care Excellence (NICE). Intravenous fluid therapy in adults in hospital. www.nice.org.uk/guidance/ cg174. Accessed August 21, 2019. testing will let you know if something is not right and will allow for early detection and treatment.

6. Holliday MA, Segar WE. The maintenance need for water in parenteral fluid therapy. Pediatrics 1957; 19(5):823-832. pmid:13431307

7. Appel L, Foti K. Sources of dietary sodium: implications for patients, physicians, and policy. Circulation 2017; 135(19):1784-1787. doi:10.1161/CIRCULATIONAHA.117.027933

8. Harnack L, Cogswell ME, Shikany JM, et al. Sources of sodium in US adults from 3 geographic regions. Circulation 2017; 135(19):17751783. doi:10.1161/CIRCULATIONAHA.116.024446

9. Sterns RH. Pathophysiology and etiology of the syndrome of inappropriate antidiuretic hormone secretion (SIADH). www.uptodate. com/contents/pathophysiology-and-etiology-of-the-syndrome-of-inappropriate-antidiuretic-hormone-secretion-siadh. Accessed August 21, 2019.

ADDRESS: Robert Lichtenberg, MD, Department of Internal Medicine, NHS Lothian, 3231 South Euclid Avenue, Suite 203, Berwyn, IL 60402; rlichte@lumc.edu 